Stellenbosch Theological Journal 2017, Vol 3, No 1, 309-326

DOI: http://dx.doi.org/10.17570/stj.2017.v3n1.a14

Online ISSN 2413-9467 | Print ISSN 2413-9459

2017 (c) Pieter de Waal Neethling Trust

\title{
Preaching and performance: Theo-dramatic paradoxes in a South African sermon ${ }^{1}$
}

\author{
Nell, Ian A \\ Stellenbosch University \\ ianell@sun.ac.za
}

\begin{abstract}
Preaching and performance is a relatively recent development in homiletical discourses and preaching practices. There is much promise in approaching preaching in this creative way. Attention will be paid to different promises related to this homiletical approach. In a next round of reflection the attention shifts to the way in which a specific approach to performance, also known as theo-drama, can not only enhance the preaching act, but also helps to understand the paradoxical role of the preacher, the audience and even God in the preaching event. This will be illustrated by looking at one of the sermons of John de Gruchy, which he preached in a very specific time in the history of South Africa. Attention will also be given to the way in which he performed a prophetic and therefore paradoxical role in his opposition to the apartheid government.
\end{abstract}

Key words

Preaching; theo-drama; performance; John de Gruchy; South Africa

\section{Introduction}

David Ford starts his 2011 publication The future of Christian theology by asking the question: 'How might Christian theology in the twenty-first century be creative and wise?' (2011:xi). He finds part of his answer in the

1 Paper delivered at the $11^{\text {th }}$ bi-annual meeting of the Societas Homiletica, Stellenbosch, South Africa, 11-16 March 2016. The theme of the conference: Preaching promise within the paradoxes of life. 
promise of the dramatic and therefore performative aspects of Christian theology. According to him, it is because of the close relationship that one finds between drama and the popularity of narratives as well as the many features that they have in common. He describes how drama, like life in general, develops and unfolds over time:

It can have plots and sub-plots; major and minor characters and events; clashes of people, ideas, and perspectives that may or may not be resolved; loose ends and mysteries; intensive dialogues, soliloquies, and cries; prose, poetry, and song; wisdom and foolishness; tragedy and comedy. It is able to convey the dynamic particularity of human existence, with its physicality, surprises, initiatives, contingencies, necessities, tensions, and multileveled complexity (2011:23).

In this short description by Ford one already senses a number of 'promises' concerning a dramatic approach to Christian theology. It is especially what he calls 'the dynamic particularity of human existence' that gets the attention of scholars interested in the close connection between promise and preaching, the theme of our conference. But this is not the only promise of a dramatic approach for preachers. There are more promises with which Ford helps us:

It may present large overviews of life or delve into the intimate interiority of one character, but its core perspective is that of characters and events in interaction, irreducibly social. As it unfolds, a drama invites us to become engaged, to inhabit its world, and to look forward its yet open ending (2011:23)

If one reads this passage through the lenses of promise, preaching and paradox as some of the keywords of the conference, Ford's invitation to become engaged in the drama of life and to inhabit another world with an open ending is music to the ears of a homiletician. In the invitation letter that we received for the conference I read that

Preaching is always somehow connected to a vision of 'a good life'. In this aspect, it might be a challenge to reclaim even 'prosperity' as a positive term in preaching - connecting it with God's promise and with the hope for a better life. 
With this in mind, the basic research questions of the paper could be stated as: What is meant by the promise of performing the Gospel seen from a preaching point of view and in what ways can a theo-dramatic approach help a preacher to cope with the paradoxes of life in specific contexts? The questions will be answered by firstly giving some clarification on what is understood by the promises of a theo-dramatic approach to preaching. Secondly, attention will be given to the ways in which performance and preaching are interrelated. In the last section of the paper I will take a closer look at the way in which the previous insights can help to gain some understanding of the paradoxes involved in all of this by analysing a sermon of John de Gruchy. He preached the sermon in a very 'paradoxical time' in the history of South Africa, just after the release of President Nelson Mandela, but before the first democratic elections.

\section{A promising approach}

The promise of a theo-dramatic approach to theology as a kind of metatheoretical perspective can be traced back to the influential work of Hans Urs von Balthasar (1988). ${ }^{2}$ He referred to God as the most important 'character' in the Christian drama and from there developed the concept of 'theo-drama' (the God-human drama). His main argument relates to the way in which God's involvement in the world can be best described by making use of dramatic categories. In this regard the Christian theo-drama has an Author who is also the main character on the stage. According to

2 Theo-drama is a term that was developed by Hans Urs von Balthasar in a series of books published in the early 1980s. Theological dramatic theory takes seriously the narrative or dramatic way that God reveals Godself. God is seen as acting first within the inner relationships of love inside the Trinity, but then also in relation to the world through acts of creation, redemption and glorification. Theo-drama also implies that we, God's creatures, are invited to find our own stories taken up into the larger Story of the Trinity. According to Von Balthasar (1988), it is an approach that has the potential to combine a number of theological methods by making use of dramatic categories. Seen from this perspective the world becomes the stage on which God's story is dramatically performed with the faithful having the responsibility to act with integrity in a community of love and justice.

There is an interest in the potential of drama from a diversity of backgrounds and in most of the disciplines within theology. For example in the New Testament: Wright, N.T. (1992) and Anderson, B.W. (1988); church history: Quash, B. (2005); systematic theology: Brown, D. (2008), Vanhoozer, K.J. (2005) and Von Balthasar, H.U. (1988); practical theology: Osmer, R.O. (2005), Healy, N.M. (2000) and Childers, J. and Schmit, C.J. (2008). 
Quash (2005), who also makes use of the insights of Von Balthasar and Hegel, the plot of the drama starts with creation, moves to the story of Israel, continues with the later prophets and reaches its climax with the Gospel accounts of the life, death and resurrection of Jesus Christ. The next act is the era of the early church, and the New Testament also refers to a final act with an eschatological view of God's consummation of all. This overarching narrative, from creation to the culmination of history, can be seen as the meta-theoretical framework for Christian understanding and identity formation over the past two thousand years. In this regard Von Balthasar makes use of Hegel's distinctions between drama, epic and lyric and shows the role of each, but also points to the fact that drama can be seen as the most important of the three because of the overarching role it plays (Ford 2011:25).

Quash (2005:39-51) discusses drama, epic and lyric as very useful, and in the light of the conference theme one can say 'promising', categories to describe different kinds of theologies and even ways in which people believe. One has to understand that they function as ideal types in the sense that one cannot compare them to any actual theological position, but they do help one to point to certain tendencies.

The epic, on the one hand, functions in the form of a monologue and tries to describe as objectively as possible God, humans, events and ideas. An epic approach works with the objective side of things as well as comprehensive structures and does not allow much space for paradoxes, ambivalence, irony and different levels of meaning.

The lyric, on the other hand, is subjective and interested in self-expression in the current moment. Between God and humans there is an intense relationship with many ups and downs. Feelings and personal and subjective truth is the focus here, often in the shape of personal confessions. In this regard individual perspectives and unconscious motives with different worldviews are on the foreground in a lyrical perspective and it looks as though an overarching structure of meaning is not possible.

Herein lies the strength of a dramatic approach because it is in the position to embrace the objective and subjective and at the same time to keep the idea of a plot intact without suppressing the complexity, diversity, motives, ideas and the personal. It is the result of the fact that the focus is on the 
characters and events that are in interaction with each other and prevents that the balance falls either to the side of the inner and personal of the lyrical or to the side of the impersonal and objective of the epic. In this regard Ford (2011:27) summarises it in the following way: 'Human freedom is fulfilled in involvement with God and God's purposes, and this means constant discernment of vocation and responsibility within an unfolding drama whose central act is the life, death, and resurrection of Jesus Christ'.

When one starts to look for more specific promises of a theo-dramatic approach, especially related to homiletics, it can be summarised, according to Johnson and Savidge (2009:11), in three words: incarnate, communal and presence.

The first promise relates to the fact that we are all as living human beings incarnated characters in the theo-drama. It is this personal embodiment that helps one also to understand the important focus on Christ becoming a human person. Through Christ God became incarnated and figuratively 'pitched his tent amongst us' (John 1:14). Preaching points the finger to this main character of the drama (Cilliers 2004) and accepts the invitation to join Him on the stage (Vanhoozer 2005).

The second promise for preaching relates to the communal and points to the fact that the actors participating in a play normally do that in front of a live audience. This communal and relational aspect of the theo-drama also reflects on the reciprocal relationship between the Triune God as Father, Son and Holy Spirit. Preaching lives from and is inspired by the mystery of the Trinity, especially in the sense of the relationship between persons and community, which according to Volf (1998) is indeed 'after our likeness'.

The third promise of a theo-dramatic approach for preaching concerns the relationship between the actors and the audience in the sense of mutual interaction and influence resulting in a certain presence. These interactions and influences also create the possibility of the presence of God, opening the opportunity for the transformation of the world through grace and love.

Even at a first glance one can already sense the paradoxical nature of all three of these concepts if one uses the following dictionary definition for 'paradox': 'a situation or statement that seems impossible or is difficult 
to understand because it contains two opposite facts or characteristics' (Cambridge Online Dictionary, 2016). From the discussion above, we see the paradoxes: God is Spirit and eternal, but becomes incarnate; an individual person is drawn into and participates in a communal activity; and God is through his Spirit elusive, but present. ${ }^{3}$ Ellul (1985:24) even refers to the radical character of paradox when he writes that paradox 'is something situated beside or outside the doxa (opinion). The paradox is free of all doxa, but at the same time calls the doxa into question'. Looking at theo-drama through the lenses of promise and paradox one can see in what ways it can help preaching to move into the challenging world of situating (performing) things outside the normal opinion and in that sense calling what seems obvious into question and making the impossible possible. This brings us to the next section in which the promising relation between performance and preaching will be the focus of attention.

\section{The promising relation of performance and preaching}

The rich diversity of preachers, personalities and styles of preaching is as fascinating as the plurality of humankind. What one can say without fear of contradiction is that any person with the courage to venture onto a pulpit finds him-/herself in the 'promising sphere' of the 'performative'. But because performance relates to persona, styles of preaching and the authenticity of the preacher, the performative also evokes a number of questions and can lead to contestation. The promise can therefore also be unfulfilled or can become unsatisfactory. It is also not without reason that hypocrisy is one of the most serious accusations made against the church by people not belonging to the church, specifically referring to the role and performance of preachers. At the same time the need exists for dynamic and energetic preachers and one often finds 'dynamic' and 'passionate' preachers high on the list of expectations from searching committees of churches and denominations (Childers \& Schmit 2008:13-14).

It is within this paradoxical situation that I want to share some thoughts that might help to inform the promise of the performative in the preaching event. It is obvious that there are a number of aspects on which one could

3 Cf. the work of Terrien (2000). 
focus ${ }^{4}$ but keeping the analysis of De Gruchy's sermon in the last part of the paper in mind, I want to focus on what Wilson (2008:37) describes as 'the Life and Death of Now'. Wilson explores the temporal element of performance and focuses on the theological implication of the 'now' in the preaching. I am of the opinion that one finds in the aforementioned an important key that can help to unlock a better understanding of the paradoxical nature of the preaching event, as hopefully also will become clear in the discussion of the sermon by De Gruchy.

Wilson (2008:37) starts his chapter with the following conviction:

Performance is a temporal phenomenon, an act located in time.

Preaching as performance normally focuses on the present moment, on orality and aurality, memory, delivery, bodily enactment, and articulation of meaning in the 'now' before a congregation. Performance is a more robust word than delivery and may be better able to account for both divine and human activity in preaching. Performance is in a moment: until the notes of the musical score have been sounded, there is no music.

Wilson (2008:37-52) explores four perspectives of the present moment or 'the now that is oriented to the past, present, and future, as well as to the death of now and of the self that is needed in performance. In such death, preaching participates in the new life of Christ'. Taking these four perspectives as framework, a short description of each will be given. Before I get to the description, a word or two by way of introduction is necessary. On the wall of a building in Oranienburger Strasse in Berlin, Germany, one finds a painting of the face of a human person with the following enticing words above the face: 'How long is now' (see Figure 1). The words are without a question mark, which already points to the paradoxical nature of the 'now'.

4 Cf. in this regard 12 different perspectives on performance and preaching in the work edited by Childers and Schmit (2008). 


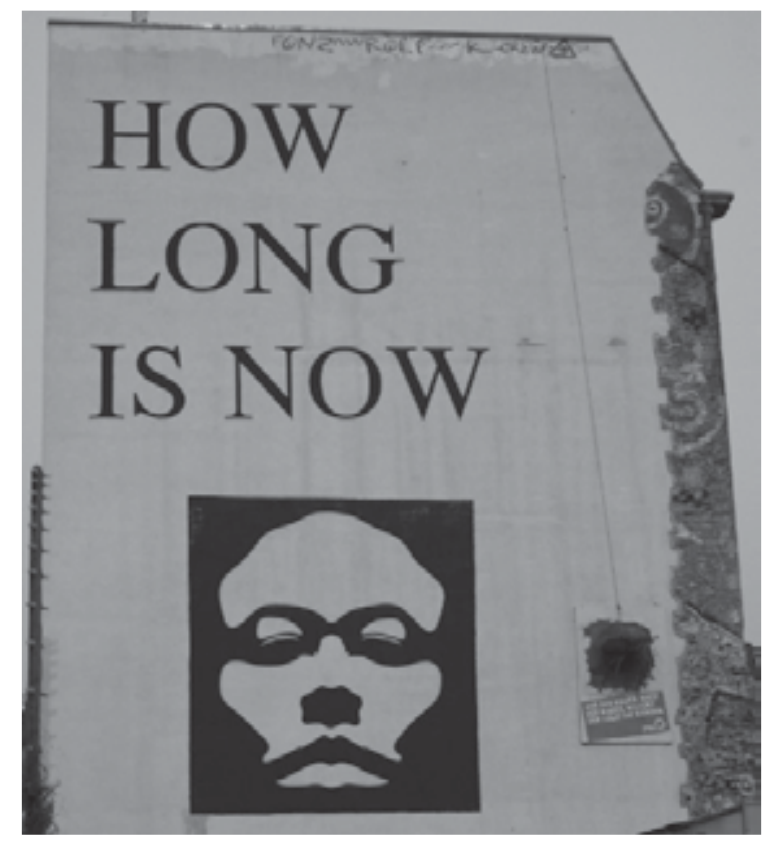

Figure 1: How long is now

One of the ways to look at the 'now moment' is to move away from a onedimensional understanding of time as a straight line with the now as a point on the line and the past and the future divided by this point. A more imaginative way to look at time and the now is to see it as a wave in the ocean moving towards the coastline (cf. Von Baeyer 1984:9-31). The wave has an origin, be it the wind or because of sea currents, and therefore one finds a continuous moving and an ever-changing present. The crest of the wave is the highest point of the wave with a trough behind and in front of the wave and two rising angled surfaces on both sides. Underneath the surface there is not much of the wave visible and it is only as the wave approaches the coastline and breaks on the rocky cliffs that one can actually see the result.

According to Wilson (2008:39), linking on to the thoughts of Von Baeyer (1984), this three-dimensional aspect of the current moment helps one not to think statically about time and the now, but as a movement or an everchanging present. It also helps to approach different aspects of the now in new ways. The wave in other words consists of a 
'front sloped in the direction it is moving, a curl or breaking crest, and a backside. The backside of the wave looks to the past, the front side looks to the future, and the break is the event of the oral delivery, the part of the wave that normally gets most attention in performative studies' (Wilson 2008:39).

With this in mind, a few thoughts follow on the different dimensions of the now in the preaching performance.

\subsection{Now and the past}

In the discipline of performance studies, Pelias and Van Oosting (1987:219) speak about 'aesthetic communication' and show that studies in performance relate inter alia to the interpretation of texts and more specifically focus on the performative and aesthetical nature of human discourse. According to Wilson (2008:39-40), preachers normally focus on the interpretation and hermeneutics of texts because of their education and training and therefore their attention is normally on the backside of the wave, with the result that a considerable part of the performance takes place in the event of looking back. The performative in these situations depends on good and sound interpretation of texts.

Lash (2005:42) links the focus on the past of the performance of interpretation to the faith community when he writes: 'The fundamental form of the Christian interpretation of scripture is the life, activity and organization of the believing community'. A great deal depends on looking back into history to try to understand something about the history and interpretation of these texts from the past and their wirkungsgeschichte through the ages. Wilson (2008:42) therefore writes: 'Much of what happens in the now is orientated toward the past, as in plain pulpit activities of recalling, rereading, reciting, re-enacting, reminding, repeating, reemphasizing, and recapitulating'.

\subsection{Now and the present}

Reflection on the now is in essence paradoxical because we do not possess the necessary means to do that and because of the fact that now also does not have any duration. Therefore Wilson (2008:41) writes:

Now is of course a largely human construct, the product of how we are conditioned to think, and every now is composed of many other 
nows - not just the nows we recall: the starlight we see is now from millions of years ago; the now of thunder comes to us seconds after the now of the lightning; the texts that we plan to read originate in a former now and will be encountered in a future now.

For preaching it is important to take the layered character of the now into consideration and once again not to think of the now as a dot on a straight line. In light of a theo-dramatic approach with the focus on the performative the now can take on many different forms, such as a changing stage, a thickening plot, the appearing and leaving of characters, a congregation participating as an audience and a living God acting as main character inviting us to partake in the drama of life.

It is in this regard that Bartow (1997:53) refers to the now as 'turning ink into blood' where the actio divina encounters the homo performans. Cilliers (2015:155) even goes further and links time to space. He writes: 'In preaching, we do not only celebrate the realities of time and space, but especially their coincidence (i.e., meaningful interaction) as kairos in God's presence'. The now in preaching therefore culminates in this kairos of God's presence and interaction with human beings. ${ }^{5}$

Wilson (2008:41) sees the now not only as an incarnational moment, but as part of a process of the Word becoming human where one can describe it as a performance that moves through time where much happens before the actual performance of the sermon. The crest of the now in the sermon therefore includes many things happening on the back side of the wave in terms of preparation and the necessary attention needs to be extended towards the past by way of reviewing, remembering and reframing.

\subsection{Now and the future}

With the inclusion of the word 'promise' in the theme of our conference we are indeed looking towards the future and at the front side of the wave

5 Wilson (2008:42) also warns about theological problems with the instant and now: "Attempts to limit performance in preaching to the present now also run into theological difficulties: too much emphasis is put on the performance of the preacher and not enough on the performance of God. The encounter of the actio divina with the homo performans has its primary location in the now, yet in fact it may happen as much along the way to the pulpit in sermon preparation as it does in the pulpit when performance is public". 
of time with anticipation and hope. Micks (2002) describes Christian worship as 'the future present' and therefore interprets it as one of the most important phenomena of worship. Nowhere else do we find the promise and hope of now and the future more vividly described than in Jesus' own proclamation about the radical breaking in of the Kingdom of God into the present (Mark 1:15). Wilson (2008:44) writes: 'every moment announces the transforming presence of God. The preacher also proclaims the arrival of God's future, and in so doing performs that future in Christ's name'.

One of the best ways to understand the performance side of the now and the future in the preaching event is to understand it in the light of the Trinitarian concept of perichoresis, understood as the mutual indwelling or dance of the persons of the Trinity. Migliori (2004:70) makes use of this concept to point to the way that the preacher and the Holy Spirit work together in giving birth to the sermon with anticipation and hope. Wilson (2008:46) gives an Christological perspective to the future-orientated process of the sermon when he writes:

In effect what happens in the sermon is that the preacher and the congregation participate in the new creation promised by Christ and realized even in the moment. God inaugurates in the now a new realm of the future in which justice, kindness, and humility reign.

Introducing the role of Christ, we move in the direction of the next aspect of the now and preaching, namely the death of now and of the self.

\subsection{The death of now and of the self}

According to Wilson (2008:47), '[p]erformance requires death. The most significant performance of preaching is God's act, the actio divina. The preacher, like any performer, gives over himself or herself to the performance, that is, to God'. This is also the mystery of the preaching event and it is not without reason that Calvin understood this moment in a sacramental way. He understood the words of the preacher as the offering of signs where in the act of preaching the Spirit of God uses the words of the preacher as means of God's grace. In a mysterious way the Spirit therefore transforms the words of the preacher into signs of grace in the space between the mouth of the preacher and the ear of the hearer (Leith 2010:20). 
When Purves (2007) speaks about the crucifixion of ministry, it can be applied in the same way to the performance of preaching. Giving yourself to God in preaching means crucifying and dying to the self to live for God. In that sense the well-known concept of Christ's kenosis (emptying Himself) (Phil 2:6-11) is helpful for what is also supposed to be happening in the performance of preaching. It is a dying of the ego to become open to the other and ultimately to the Other. Wilson (2008:49) summarises: 'The preacher must enter death through performance: the performance end, the ideas, emotions, and gestures are released, and for the preacher the sermon is over'.

\section{Preaching as theo-dramatic paradox: A case in point}

In the combination of preaching and performance in the light of 'the now', something of the theo-dramatic paradox becomes visible. Making use of the dramatic categories of drama, the different paradoxes can be named as a paradoxical stage providing space for a plot full of paradoxical performances by characters acting within these paradoxical contexts.

\subsection{A paradoxical stage}

The sermon of John de Gruchy ${ }^{6}$ was preached on 11 November 1990 in the Rondebosch United Church in Cape Town exactly 10 months after the release of President Nelson Mandela from prison and in the liminal and therefore paradoxical time between the old and the new dispensation in South Africa - one could also say between the already and the not yet. ${ }^{7}$ This was a time full of promise and expectation for the birth of the New South Africa, but also uncertainty about what to do with the past. It was during the previous week that the National Church Leaders Conference was held in Rustenburg in the old Transvaal. More than 250 church leaders from 80

6 John de Gruchy is emeritus professor in Christian Studies at the University of Cape Town and one of the greatest and most respected South African theologians of the past five decades. His work has left a fixed mark on both the South African and the international theological landscapes.

7 De Gruchy (2014) writes on the back cover of his latest book: "Theology is about life in its complexity and ambiguities, pain and joy, ugliness and beauty, lies and truth, oppression and struggles for justice. But theology specifically seeks to discern meaning within these paradoxes of life from the perspective of informed faith, realistic hope and self-giving love". 
different denominations attended and De Gruchy was invited to be one of the speakers. According to De Gruchy (1990:1), '[i]t was a historic event, and I am sure that it will have a very significant impact on the life of both the church and the nation'.

He continues with the intention of his sermon and points to the fact that he didn't want to tell the congregation about the Conference but rather wanted to reflect on the confession of guilt, which took place during the Conference. In his own words (1990:1):

It all began with the paper read by Professor Willie Jonker of the $\mathrm{NGK}^{8}$ in which he confessed both his own guilt, and that of his Church, for their role in creating and supporting apartheid. This was followed by a wonderful moment in which Archbishop Desmond Tutu embraced Professor Jonker in an act of forgiveness.

This was a paradoxical act for two people on different sides of a table that kept them apart for many years, but also a moment full of promise.

\subsection{A plot of paradoxes}

De Gruchy (1990:1) continues to explain that the focus was on 'the importance of the confession of sin and guilt both in our lives as individual Christians and as a church'. From this it is clear what the theme of his sermon would be, also in the light of the three passages from Scripture that he read: Psalm 51, James 5:13-16 and Luke 7:36-50, namely the importance of confession. But then he started his sermon with the paradoxical move by pointing to the importance of worship: 'Our Sunday worship rightly begins with praise. Praise of God the creator and redeemer, praise of God; the Father of our Lord Jesus Christ...Our chief end, so the Westminster catechism reminds us, is "to glorify God and enjoy God forever".

He started the second paragraph of his sermon with the following revealing words:

8 NGK stands for the Nederduitse Gereformeerde Kerk, which is the Afrikaans for the Dutch Reformed Church. In the English-speaking world the abbreviation NGK was often used to refer to this denomination, which forms part of the broader Reformed family of churches in South Africa. 
God does not first, like some earthly potentate, demand of us that we prostate ourselves in humiliation before him. That we crawl on our knees to his throne. Confession of sin arises out of our praise. The liturgy begins with praise and then very naturally it leads us to acknowledge and confess our sins (De Gruchy 1990:1).

He surprised his audience with this paradoxical statement and explained that it is precisely this awareness of God and his majesty as revealed in the cross that awakens in us an awareness of our sins.

These paradoxical statements in the introduction to the plot of his sermon gave structure to the rest of his argument. On the second page he discusses how we often do soul-searching to look for the hidden recesses of our lives to find some secret faults and sins and how this can become pathological. He states (1990:2): 'We start and end with our sins. Whereas the purpose of confession, awakened by the Holy Spirit, is to bring us to the fullness of the life of God'. On the following pages of his sermon he uses different examples to illustrate this central paradoxical truth of a life of faith, and makes the link to the Scripture passage from Luke 7:36ff. - about the story of Jesus being anointed with oil by the woman whom the Pharisees had rejected as sinful. As we know, Jesus allows her to anoint his feet, much to the Pharisees disgust. De Gruchy (1990:5) states:

Her act of love was out of gratitude for being accepted just as she was by Jesus. It was an act of penitence. 'Then Jesus said to her, "Your sins are forgiven. ...Your faith has saved you; go in peace"' (Luke $7: 48)$.

In the following pages he explains that this is the way the Gospel operates because Jesus accepts us as we are, but in doing so he also enables us to see our need and to become what he can make us. On page 3 he says: 'Our greatest sin will always be ingratitude - a lack of thankfulness expressed in the way in which we live'. Making use of Romans 5:8 he points to the fact that this is the way that God demonstrates his love for us. In the rest of his argument he discusses a number of topics, inter alia pointing to the fact that sin has primarily to do with relationships in that it destroys our relationships with God and with other. He discusses three different ways in which we can confess our sins and even points to the interesting differences - one could say paradoxical practices - between the ways that Catholic and Reformed people understand and participate in acts of confession. 
Towards the end of his sermon, he once again made an interesting observation. He states (1990:5): 'But true confession may also go beyond simply saying 'I am sorry', it may require something even more costly'. He refers to a cartoon that appeared in the daily newspaper, the Weekly Mail, but with this we move towards a number of interesting characters that become part of the plot as the sermon reached its climax, which is also the topic of the next section.

\subsection{Characters acting in a paradoxical context}

De Gruchy describes the cartoon he refers to in the following way:

In the Weekly Mail this week there was a cartoon reflecting on Professor Jonker's confession and Archbishop Tutu's act of forgiveness. It portrayed a Catholic confessional. In the one side sat the NGK, in the other sat the Archbishop. The Archbishop was depicted as pronouncing what acts of penitence now needed to be done: 'Sinning against your brother ... well that's ah ... 20 hail Mary's ... ah ... land redistribution ... ah.... Funny as the cartoon may be, it really is making a vital point.

De Gruchy (1990:5) then explains that 'confession means a willingness to put right, as far as we can, what our sins have made wrong'. Later, in the 1990s, Archbishop Tutu was instrumental in leading the Truth and Reconciliation Commission to give the perpetrators the opportunity to put things right what sins have made wrong. Many people today feel that unfortunately the process was not completed and some commentators see the unrest and even student protests we are experiencing at the moment in South Africa as a result of the fact that we had a process of reconciliation but without justice and restitution. Once again it is nothing less than a paradoxical context that we found during the 1990s and a context we still find ourselves in today.

De Gruchy (1990:5-6) ended his sermon by referring to the wonderful story of Zacchaeus in the New Testament. He gave a short retelling of the story by describing the way Jesus stopped to speak to Zacchaeus, the tax collector, who was sitting in a tree watching Jesus pass by. Jesus not only stopped to speak to him, but also gave him back his dignity and made his life whole again by forgiving him his sins and faults. And then he ends his sermon by quoting Luke 19:8: 
'Zacchaeus stood up and said to the Lord, "Look, Lord! Here and now I give half my possessions to the poor, and if I have cheated anybody out of anything, I will pay back four times that amount." Jesus said to him, "Today salvation has come to this house ..."”

In what could be interpreted as the 'death of now and of the self' in the character of Zacchaeus, the final paradox of the sermon is exemplified.

De Gruchy's sermon illustrated in different ways the many paradoxes at work in all the dimensions of performing the now. He linked his thoughts to the backside of the wave of time, created some hope on the front side of the wave with a future full of forgiveness and finished with the crest of the wave breaking through the death of now and of the self by making use of the story of Zacchaeus.

\section{Conclusion}

The promise of performing the Gospel understood in the light of preaching as theo-dramatic paradox proved to be an exciting and inspirational approach to the act of preaching. Looked through the lenses of the past, present and future, a multi-dimensional frame of interpretation can be developed in which the death of now and of the self can be seen as the culmination of the performance of preaching, pointing towards the mystery of God. The promise of this approach became clear in the different dimensions of theo-drama as illustrated through the sermon performance of De Gruchy, not to be a blueprint or model for preaching, but opening up creative and promising new possibilities in theory formation on preaching.

\section{Reference list}

Anderson, B 1988. The unfolding drama of the Bible. Fourth edition. Minneapolis, MN: Fortress Press.

Bartow, CL 1997. God's human speech: A practical theology of proclamation. Grand Rapids, MI: Wm. B. Eerdmans.

Brown, D 2008. God and mystery in words: Experience through metaphor and drama. Oxford: Oxford University Press. 
Cambridge Online Dictionary. 2016. Paradox. [Online]. Available: http:// dictionary.cambridge.org/dictionary/english/paradox

Childers, J (Ed.). 2001. Birthing the sermon: Women preachers on the creative process. St Louis, MO: Chalice Press.

Childers, J. \& Schmit, C.J. (Eds.). 2008. Performance in preaching (engaging worship): Bringing the sermon to life. Grand Rapids, MI: Baker Academic.

Cilliers, J 2004. Die lewende stem van die evangelie. Stellenbosch: AFRICAN SUN MeDIA.

Cilliers, J 2015. A space for grace: Towards an aesthetics for preaching. Stellenbosch: AFRICAN SUN MeDIA.

De Gruchy, J. 1990. Sermon preached at Rondebosch United Church, Cape Town, 11 November.

De Gruchy, J 2014. A theological odyssey: My life in writing. Stellenbosch: AFRICAN SUN MeDIA.

Ellul, J 1985. The humiliation of the word. Trans. J.M. Hanks. Grand Rapids, MI: Wm. B. Eerdmans.

Ford, DF 2011. The future of Christian theology. Chichester: WileyBlackwell.

Healy, N 2000. Church, world and the Christian life: Practical-prophetic ecclesiology. Cambridge: Cambridge University Press.

Johnson, TE \& Savidge, D 2009. Performing the sacred (engaging culture): Theology and theatre in dialogue. Grand Rapids, MI: Baker Academic.

Lash, NLA 2005. Theology on the way to Emmaus. Eugene, OR: Wipf and Stock.

Leith, JH 2010. John Calvin's doctrine of the Christian life. Eugene, OR: Wipf and Stock.

Micks, MH 1970. The Future Present: The Phenomenon of Christian Worship. New York: Seabury. 
Migliori, D 2004. Faith seeking understanding: An Introduction to Christian Theology. Third Edition. Grand Rapids: Eerdmans.

Osmer, R 2005. The teaching ministry of congregations. Louisville, KY: Westminster.

Pelias, RJ \& VanOosting, J 1987. A paradigm for performance studies. Quarterly Journal of Speech, 73(2):219-231.

Purves, A 2007. The crucifixion of ministry: Surrendering our ambitions to the service of Christ. Downers Grove, IL: InterVarsity Press.

Quash, B 2005. Theology and the drama of history: Cambridge studies in Christian doctrine. Cambridge: Cambridge University Press.

Terrien, S 2000. The elusive presence: Toward a new Biblical theology. Eugene, OR: Wipf and Stock.

Vanhoozer, KJ 2005. The drama of doctrine: A canonical-linguistic approach to Christian theology. Louisville, KY: Westminster John Knox Press.

Volf, M 1998. After our likeness: The church as the image of the trinity. Grand Rapids, MI: Wm. B. Eerdmans.

Von Baeyer, HC 1984. 'Gravity'. In Rainbows, Snowflakes, and Quarks: Physics and the World around us. New York: McGraw-Hill, 9-31.

Von Balthasar, HU 1988. Theo-drama: Theological dramatic theory. Vol. 1: Prolegomena. San Francisco, CA: Ignatius.

Wilson, PS 2008. Preaching, performance, and the life and death of now. In J. Childers \& C.J. Smith (eds.). Preaching: Bringing the sermon to life. Place: Publisher, first-last page.

Wright, NT 1992. The New Testament and the people of God. Minneapolis, $\mathrm{MN}$ : Fortress Press. 